\title{
Photojournalism in Pakistan: Ethics and Responsibilities Analysis of Urdu Newspapers Front Pages
}

\author{
Muhammad Wasim Akbar ${ }^{1}$, Muhammad Riaz Raza ${ }^{2 *}$ Shahid Hussain ${ }^{2}$ and Zafar Ali ${ }^{2}$
}

${ }^{1}$ Associate Professor, Department of Mass Communication, Gomal University, Pakistan

${ }^{2} \mathrm{PhD}$ Scholar, Department of Mass Communication, Gomal University, Pakistan

\begin{abstract}
Photojournalism occupies very important place in media in this digital age of communication. Since the picture is most effective tool of communication, it conveys meaning in the most attractive and truthful manner. At the same time, it is very often exploited for the selfish ends of the media organization irrespective of the values and norms of the society. It not only goes against the values and norms of the society but it also depicts in picture the vice and immoralities in attractive manner. This paper explores the practices and preferences of Pakistani print media in the flourishing field of photojournalism. For the purpose, front pages of three leading Urdu newspapers The Daily Jang, Express and Nawa-e-Waqt were selected to measure the nature of photojournalism in print media. The researchers selected four major events of suicide attacks in the years 2007, 2010 and 2011. These bloodiest events covered by newspapers extensively with images and body parts of victims on front pages. To catch maximum readership the print media frequently displayed bloody and violent terrorize images of the victims in suicide attacks, bomb blasts, firings and accidents on front pages. These newspapers did not consider ethical codes as an important and essential component for photojournalism.
\end{abstract}

\section{Introduction}

The constant war on terror of this region bears some unethical violent and terrorize images on the part of transitional media. One can find easily the terrible and violent pictures in our mainstream print media.

The Urdu press has been publishing a number of images of bloodshed, images of burned people in their front pages. We have witnessed some recent events in Pakistan like earth quake (2005), Lal mosque operation (2007), suicide attacks, bomb blasts, in major cities and wave of deaths in Karachi in which print media covered hundreds of photo shoots. There is a question mark on their ethical approach while photographing, framing, highlighting and presenting the images of bloody, burnt body parts and human remains in their front pages.

The study shows that these images have, no doubt, enhanced the informative value of the events but it lacks in ethics of photojournalism. Pakistani Urdu language newspapers are acting on Hedonism model which says "do what feels good" whatever the cost might be. They prefer to publish a photo on front page only for commercial purposes and to increase the selling of their newspapers.

The analysis has consisted of three maintstream newspapers, Daily Jang, Nawaewaqt and Express. The study further focused on four violent incidents during the war against terror. Two incidents of the year 2007 -- Miss Benazir Bhutto's arrival in Karachi and BB's death incident in Rawalpindi, while two incidents during the last year - suicide attack at the Shrine of Data darbar Lahore and a recent death of Col. Moammar Qadafi were selected. The main reason to select the incidents from different years was just to correlate the consistency in policy regarding covering and publishing victims and their remains of suicide attacks in the front pages of newspapers. Interestingly, the researchers have not observed any change while examining immoral and unethical stuff. These papers have been publishing images of bloody dead bodies and their remains in main pages of newspapers. They are not much worried about the violation of journalistic ethics and norms.

\section{Literature Review}

Nobody can ignore pictures. Whether the readers read the story or not but they notice of photo. Due to the advancement in technology has changed the whole phenomena of photojournalism in print media in the recent decades. Photo with news item enhances effectiveness and comprehensiveness of the credibility element. There is no concept of modern journalism without photos as these are part and parcel.

\section{Juha [1] says that:}

The photos are like adds in that glancing moment to trap the reader. If a photo is interesting enough, the reader will stop to it and read the caption and if the interest stays there the title of the article is read next. If the beginning of the article is catching enough the reader will read all of it. In conclusion only $5 \%$ of readers read an article but almost all the photos get noticed.

We can not ignore the importance of photos in present age of colorful journalism where the more focus is on layouts instead content. Interesting photos can have the ability to catch the attention of the reader. Majority of readers give attention to photos and some of them read the whole stories. Shahid [2] said that:

Every organization wishes more and more people to read their paper. Layout plays an important role in attracting the people and compelling them to buy the paper. And the layout is not possible without photos.

Newspapers are using digital techniques to develop and fascinating their papers through big size colorful photos. Readers do impress

${ }^{*}$ Corresponding author: Muhammad Riaz Raza, Department of Mass Communication, Gomal University, Pakistan, E-mail: rayyaz31@hotmail.com

Received January 16, 2012; Accepted March 19, 2012; Published March 21 2012

Citation: Akbar MW, Raza MR, Hussain S, Ali Z (2012) Photojournalism in Pakistan: Ethics and Responsibilities Analysis of Urdu Newspapers Front Pages. J Mass Communicat Journalism 2:112. doi:10.4172/2165-7912.1000112

Copyright: (c) 2012 Akbar MW, et al. This is an open-access article distributed under the terms of the Creative Commons Attribution License, which permits unrestricted use, distribution, and reproduction in any medium, provided the original author and source are credited. 
and attract through interesting photos within less time than reading a certain column or article in detail. Zaini (1988) writes that 'Photos play an important role in the newspapers and helps in projecting the true sense of news items.' For deeper impact the newspapers of present age put more and more visual and photos in their stories to enhance the credibility and readership. The latest technology in the field of images greatly changed the whole field of photojournalism. The most important point in photojournalism is accurate and objective presentation of an event. There should be a balance between written and pictorial content and it should correlate and true. The term photojournalism is fairly a new. In the old days, photographers were called as 'news photographers.' Siraj et.al [3] stated that:

The enhanced interest in photographic communication has opened new avenues for making business in newspapers and magazines. Photographers now contribute pictures in the development of photographic essays and interpretative picture stories.

No doubt new technology has opened up new horizons for photojournalism. A digital camera, cell phone, etc are being used for instant photography that was never possible in early days. It has created interest in the news items and enhanced the readership. The Pakistani media in recent years have flourished in all meanings.

Photojournalism works within the same ethical approaches to objectivity that are applied by other journalists. What to shoot, how to frame and how to edit are constant considerations. Often, ethical conflicts can be mitigated or enhanced by the actions of a sub-editor or picture editor, who takes control of the images once they have been delivered to the news organization. The photojournalist often has no control as to how images are ultimately used [4].

Photojournalism is a very powerful tool to communicate the illiterate and less educated audiences. Journalists have binding on them to shoot, frame and represent in an ethical way. In many media organizations news photographers have not any role to add their pictorial material in the newspapers. The editors and sub editors take full control to add or discard their images of the event. Therefore, in some organizations, the photojournalist is on driving seat to add pictures 'as it is' he/she shoots while in some responsible media outlets there is a mechanism to check the objectivity. They do not give any thing immoral and unethical in photography. To be sure, photographs are more convincing than words.

War on terror has become an industry of human deaths of this region which is being projected as an amusement and number game for media outlets. Nowadays, newspapers publish more and more photos to attract the readers and a handsome space of newspaper pages filled with photos. The newspapers often paste a colorful photograph of a celebrity specially beautiful female in mid of front pages without any news. The papers do not justify its policy of framing and highlighting such pictures. We find sensationalistic and manipulative images frequently in Pakistani Urdu newspapers. There are also a number of advantages of publishing photographs in newspapers for example, photos of criminals help in their search, photos of lost children and missing people help in identifying them easily. Photos of certain mishap, earth quack, flood and other calamities help in estimating this intensity or the happening of the event. Some critics of the media include sex and violence as unethical. In short all the Urdu newspapers give a reasonable and prominent place to photos. Specially, after the digital and colorful photography it becomes common and necessary part of news items. Modoodi [5] says that:
Today's newspaper is decorated with different poses of young girls, dance photos, fashion photos and photos from film industry, music shows, theatres, dancing clubs, all photos exploit and utilize beautiful females.

Sex appeal is prominent in photojournalism of this part of the world. The recent mushrooming of private TV channels has drastically changed the whole scenario of our news and information consumption pattern. Due to cross media ownership of Pakistani media landscape, the same policy of commercialism is being adopted in most of the media outlets by giving much space / time to soft and entertainment news. Fear, sex, beauty, sufferings, crime, violence, fashion, terror and shocking news are some main ingredients of our media. Most of the media outlets (Print and Broadcast) are constantly in search of sensational and shocking news which is a negative sign for the growth of media institutionalization and democracy as well. We have witnessed a recent media circus, especially TV media that has covered the issue of Pakistani Cricket Star Shoaib Malik and Indian Tennis player Sania Mirza out of proportion. It was intrusion into their private life that was not allowed legally. After the invasion of digital technology the newspapers consider photographs as an important part of any news items which is to be primed or highlighted. Glamorous culture is being promoted though projecting young females from film and showbiz. It is interesting to mention here these papers approach even to a political news using such criteria of exciting readers through short dressed females. This practice of newspapers increases viewership but the not readers. Majority of newspapers in Pakistan devote half of the front page to some advertising stuff and it is a common phenomena to use young females in shorts. Big size pictures increase the sensational value of the event. Such kind of sensational and exploitative approach has no utility to the nation. According to a survey by Weekly Asia [6] that "it was revealed that there is rush of photos of actresses and artists with costly dresses and heavy make-up trying to occupying maximum space of the newspapers and magazines." Sometimes there is no news but a picture of celebrity is published to capture the attention of the reader.

\section{According to Riaz [7]:}

Press photographers have no right to capture people's privacy. Photos of injured and dead bodies should not be published. Lady Diana always escaped photographers. The time he died, the photographers were chasing her. The press was much criticized in U.K. and people asked the govt. of making reporters responsible and they should not interfere in privacy of the people.

There are some ethics of photojournalism and photographers can not be given any privilege to invade people's privacy in the name of freedom of expression. They have some responsibilities and ethical codes to follow in all their journalistic activities. Different countries have formulated codes of ethics for photojournalism, but in Pakistan, after a long history of restrictions on media, the phenomena of media freedom is being considered as unquestionable job. Sensitized and violent images of dead bodies, are considered as exploitative and irresponsible act of the photographer or media outlet. Since war on terror is underway in Pakistan and Afghanistan, the violent acts of terrorism like suicide attacks, bomb blasts and indiscriminate firing are common things. Therefore, the newspapers and electronic media have an easy access on such images whom they use in prime places of newspapers or in other media. Martin [8] of the view that:

An understanding of a law is important to a photographer working for the media. Ignorance can result in a fine, imprisonment or payment 
of damages if the publication of a photograph leads a photographer in court. So knowledge will enable journalist to keep clear of the court.

Photojournalists and photo editors have an ethical and moral responsibility not to publish violent, sexual, offensive and terrorize images unless and until it is significant and necessary for the story. As we know, a picture is the ability to plant an image about particular person or thing. The newspapers do not much care about the appropriate size and they are also not much cautious about newsworthy of the pictures. Engineered images like projecting and digitizing small gatherings into large one and small into big one are against the norms of photojournalism. Terrifying pictures which result terror, unrest and uncertainty should not be covered. Social norms and values must be in mind while picturing and publishing on sensitive issues to avoid any unpleasant situation. In recent years there were many cases of burning alive of the dacoits in Karachi by mobs and print media publish these in most prime places. Photographing and publishing of two young brothers who were beaten by police in front of hundreds of people in Sialkot was also an irresponsible and unethical. Even some news channels repeated that footings for weeks. Such practices are clearly unethical and immoral on the part of a photojournalist and media outlet. In the light of literature review the researchers posed the following hypothesis:

H1. The newspapers use bloody, violent and terrible images on front pages and do not follow ethical codes in photojournalism.

\section{Findings}

\section{Nature of Photojournalism}

The detail of some front page photographs of Daily Jang, Nawaiwaqt and Express is given in the following:

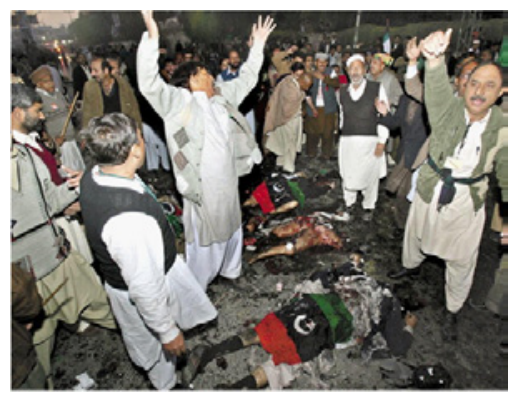

Figure 1: 28 dec 2007 Express Front Page. This image has been published by Daily Express on front page on the death of former Prime Minister Benazir Bhutto on Dec 28, 2007. After a suicide attack one can see the body parts of victims of the attack. This is a worst example of unethical practice of photojournalism.

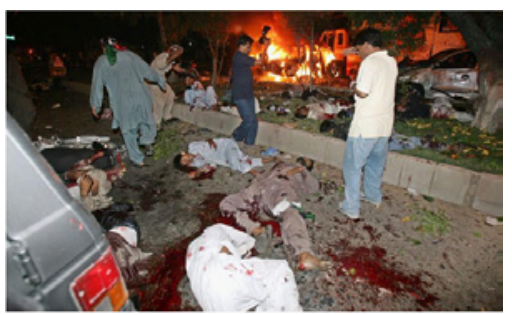

Figure 2: Express 18 October 2007 Front Page. The picture has also taken after a suicide attack at Miss Bhutto's rally in Karachi. The picture published on front page of Daily Express. Bleeding dead bodies, fire, and scenes of sorrows are captured by a photographer and published by a newspaper.

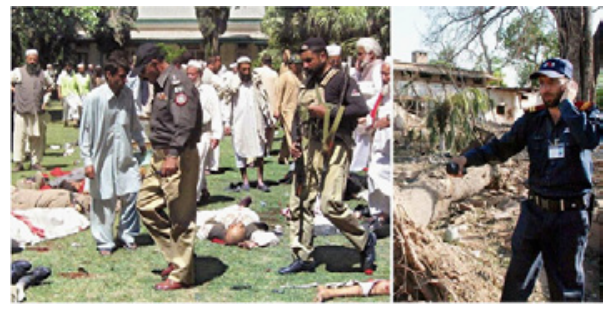

Figure 3: After a suicide attack dead bodies can be seen on the spot while another picture of destruction has joined. It is published on front page of the newspaper.

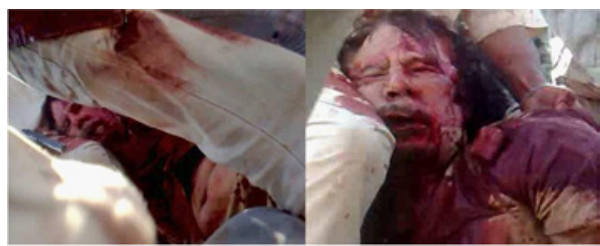

Figure 4: These two pictures of bleeding late Col. Qadafi have been published in Daily Express on 21-10-2011.

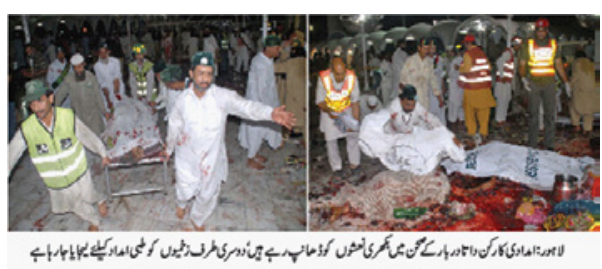

Figure 5: These two pictures have been taken and published in Daily Nawaewaqt on 2-7-2010 after asuicide attack on Data Darbar Tomb, Lahore.

The Jang, 28 Oct, 2007, Rawalpindi-Pakistan

The Nawaiwaqt, 28 Oct, 2007, Islamabad-Pakistan

The Jang, 28 Dec, 2007, Rawalpindi-Pakistan

The Nawaiwaqt, 28 Dec, 2007, Islamabad-Pakistan

The Jang, 2 July, 2010, Rawalpindi-Pakistan

The Express, 2 July, 2010, Islamabad-Pakistan

The Jang, 21 Oct, 2011, Rawalpindi-Pakistan

The Nawaiwaqt, 21 Oct, 2011, Islamabad-Pakistan

\section{Interpretation and Conclusion}

The print media has shaped a higher attentiveness toward violence in recent years after $9 / 11$ all over the world. After the invasion of private news channels in Pakistan the tastes of news consumption have been changed alot in the society. Due to the advance technology in photography and consant war on terror in the recent years have increased the ratio to cover violent and horror images in mainstream media of the world and particularly of Pakistan. Self censorship and ethical bindings are integral part of media freedom. According to social responsibility theory, the media organizations and journalists are responsible for not presenting immoral stuff to their audiences. Mushrooming of media outlets (print and electronic) in Pakistan during the last decade have multiple effects on people's psychology. Merriam-Webster defines "ethics" as, "the code of good conduct 
for an individual or group," and lists synonyms as, "morality, morals, principles, and standards." Since Media have been enjoying restrictions free environment in the country after a series of media limitations at different times. There is an ethical framework designed by print media organizations, moreover a code of ethics has also been framed by All Pakistani Newspapers Society. The ethical approach in photojournalism is an integral part of freedom of press but it has been observed that mainstream newspapers have been consciously or unconsciously involved in depicting violence as main tool to attract the readership regardless of the negative impact. Depiction of violence images has been a controvercial phenomena for media institutions and media consumers as well. The findings of the study showed that the news about violence have drastically been increased since war on terror in Pakistan. The unrest and fear of being targeted has gradually been risen during these years. The researchers also noticed that news about crime and violence became delocalized. The media love to cover an incident of violence which takes place away the media base, the media creates alertness toward terror and violence acts. A recent example is of Moammar Qaddafi (Late) when his violent death become front page headline with its bleeding dead body. The analysis show that Pakistani Urdu newspapers are prominently displaying bloody dead bodies and human remains in their main pages. Though some newspapers use small amount of pictures but they present full of terror and horror stuff to sensationalize the news. It is also observed from the analysis that there is no discrimination between suiciders and victims of these incidents while showing dead bodies or remains. USA and some other advance countries restrict the media not to show the bloody dead bodies of their soldiers of wars and citizens, and try to keep prominent of enemy's deads in their media for showing good taste. Though it is also dehumanization to project deads or their body parts in media and considered unethical and immoral in journalistic norms. It is clear from the pictures that elite Urdu newspapers in Pakistan do not take care of the journalistic norms and ethical principles in conducting their journalistic activities. It is happening at the end of a photojournalists and the desk incharge of the concerned paper. They take immediate emotional response in shape of rapid increase in their newspapers. It is the prime responsibility of the editors to make sure that images of dead body of a murder or victim are really considered necessary to tell the story. Photographers and journalists have to explain the truth and reasons of conflics rather than to show dreadful events. The competition among media outlets to break the news or to explore the event has become greater than ever before. Commercialization in media organizations has also increased such cheap thrills to catch the maximum audiences. The readers and audiences want to have detail circumstances of dreadful event and they do not want to have uncomfortable details of such events. The study shows that all the three selected newspapers covered these four deadly horrifying incidents in the prime places. It is beyond the ethical limits when such bloody horrifying images are published and it is nothing to do with responsible journalism. Due to the absence of self censorship mechanism in media organizations, the 'unchecked photojournalism' has shaped as a tool to enhance the consumers. Easy access and availability of terrible pictures and images of bloodshed is another cause which has contributed a lot in flourishing the phenomena. It is not reasoned and objective journalism rather spread of fear and horror among readers to boost commercial objectives. Unfortunately, we have a tragic and bloody incidents almost everyday as a result of war on terror. Thereore, to find burned and incomplete bloody dead bodies is not a difficult job. Our press and electronic media is using such terrible and horrifying shocking images since $9 / 11$. It is pertinent to mention here that English newspapers have some different policy while projecting such deadly events in their pages. The English press is more responsible and has ethical approach towards violence and terror etc. The people of this country were not aware of sucide bombers before $9 / 11$. The media have become habitual and made the audiences addicted to such violent images during the last decade. The question arises here that, what movties an editor has? Irresponsibility at the part of a photojournalist and an editor in the name of media freedom. Social responsibility theory works here. It is a soul responsibility of the journalist to make sure that nothing perceive wrong through its angling or priming to the news story consciously or unconsciously.

\section{References}

1. Kivekas J (2006) The Importance of Photos in Printed Media.

2. Shahid MI (1994) Introducing New Trends in Mass Communication, Car Enterprises, Lahore 76-77.

3. Siraj SA, Fairishullah (2002) Print Media, A Study Guide. Dept of Mass Communication AIOU, Islamabad.

4. http://en.wikipedia.org/wiki/Photojournalism\#cite_note-13

5. Modoodi S (1990) Islamic Publications. Lahore 70-71.

6. Weekly Asia (1987) Qoumi Akhbarat ka Survey Weekly Asia. Lahore15.

7. Riaz Saqib (2003) Jadid Sahafat Aur Ablagh-e-Aama. Urdu Science Board Lahore 96.

8. Martin K (1995) Practical Photojournalism edition. The Bath Press London, UK 167.

9. Hassan M (1990) Tasweeri sahafat, Muqtqdara Qomi Zaban. Islamabad 32.

10. Hassan M (1986) Sahafat. Ehtisam Publishers, Lahore 253.

11. Hassan M (2003) Jadid Sahafat Aur Ablagh-e-Aama. Urdu Science Board Lahore 88.

12. Patterson P, Wilkins L (1994) Media Ethics: Issues \& Cases. In Lon Hodges (Edn) Taste in Photojournalism: A Question of Ethics or Aesthetics. Brown \& Benchmark.

13. The Merriam-Webster Online Thesaurus, Ethics. 